Hocknell S.

Chewing the Fat: "Unpacking" Distasteful Encounters.

Gastronomica 2016, 16(3), 13-18.

\title{
Copyright:
}

Published as Hocknell S. Chewing the Fat: "Unpacking" Distasteful Encounters. Gastronomica 2016, 16(3), 13-18. (c) 2016 by the Regents of the University of California. Copying and permissions notice:

Authorization to copy this content beyond fair use (as specified in Sections 107 and 108 of the U.S. Copyright Law) for internal or personal use, or the internal or personal use of specific clients, is granted by the Regents of the University of California for libraries and other users, provided that they are registered with and pay the specified fee via Rightslink ${ }^{\circledR}$ or directly with the Copyright Clearance Center.

DOI link to article:

https://doi.org/10.1525/gfc.2016.16.3.13

Date deposited:

$13 / 06 / 2017$ 


\section{Chewing the Fat: "Unpacking" Distasteful Encounters}

\begin{abstract}
Fat is not only found on plates or in bellies. Fat is on the news, on reality TV, in policy, and in flesh. The stuff of fat is a matter of concern: it is too cheap, or possibly too expensive; consumers are eating too much of it to be healthy, or possibly not enough of the right sort. Fat production is reported to be too animal based, too plantation based, or too resource hungry to be sustainable; too entwined with opaque globalized networks to be fair. Yet fat, particularly the yellow fats of butter and margarine, are, for eaters of North European heritage, typically a routine part of daily life. "Unpacking" the mundane encounters between eating and eaten bodies can work to make present the ways in which the world is understood, represented, framed, and enacted. In this article I draw on this premise to explore distaste as a means by
\end{abstract}

FAT, IT SEEMS, IS EVERYWHERE. Fat is a foodstuff and a categorization of bodies and of body parts. Fat is not only on the plates or in the bellies of eaters, but is also a matter for political intervention, social concern, and public health discourses (Forth 2014). Yet for eaters of North European heritage, fats, particularly the yellow fats of butter and margarine, which are the subjects of this short article, are typically a mundane element of daily life. ${ }^{1}$ Butter has been a long-established staple of North European diets, whereas margarine can be seen to be a novel food. Patented in 1869, margarine was one of the very first industrial foodstuffs and it introduced eaters to a combination of bodies, relationships, and processes never encountered before. Hence a cultural shift was required if eaters were to learn a taste for it.

Shopping and eating practices with fats are shaped by a complex interplay of material, sensory, and symbolic factors and different consumers eat different fats in different ways. Abbots and Lavis (2013: 1) have illustrated how "unpacking the encounters" between eating and eaten bodies can work to make present the ways in which consumption can reinscribe or trouble normative knowledges and practices. In this article I draw on this premise to "unpack" which British participants in six "planned discussion groups" negotiate encounters with yellow fats amidst multiple conflicting knowledges. I demonstrate that for my research participants the distastefulness of a yellow fat did not rest in any straightforward way on a visceral disliking of the flavor of that same product. I conclude by arguing that thinking with distaste is an "unpacking" which extends discussions of the visceral to better theorize the complex interactions between embodied encounters, sense of self, and styles of valuing the stuff of fats.

Keywords: distaste, fat, materialities, visceral politics, planned discussion groups

conversations generated by six "planned discussion groups" (PDGs) (O'Reilly 2005). I demonstrate that for my participants, the distastefulness of a yellow fat does not rest in any straightforward way on a visceral disliking of the flavor of that same product. In paying attention to the ways in which my participants make and practice fat choices, distaste becomes present not simply as a "yuck" response to the unfamiliar, but something my participants use in ways that are simultaneously material, cultural, social, and political.

For this research I chose to use PDGs as the basis for scrutinizing consumer engagements with yellow fats. PDG discussions are multidirectional, and in this way are more faithful to the interactive nature of real-world decision making than are individual interviews (Lunt and Livingstone 1996; O'Reilly 2005). PDGs differ from focus groups in that participants are selected because of their relationship to each other rather than their knowledge of the subject, and the setting is familiar instead of being chosen for its "neutrality" (O'Reilly 2005). As I was seeking a diverse rather than a representative group, I used my personal networks to recruit six initial contacts. Their professions included a teacher, a shop assistant, a librarian, a personal secretary, a gardener, 
and a retired nurse. Each contact then recruited up to three friends, colleagues, or family members to join their PDG. The participants were all British, lived in a mix of rural and urban settings, were from a range of working-class and middle-class family backgrounds, and varied in age from twentyeight to seventy-three. At the start of the sessions six participants self-defined as margarine eaters, six as butter eaters, two used both and two neither.

Food "enters into what we become" (Bennett 2007: 133). Yet the mundane nature of food habits can make it hard for the researcher to access the ways in which consumption can reinscribe or trouble normative knowledges and relationships (Braidotti 2013). An advantage of using PDGs in combination with a snowballing method of recruiting participants was that within each of the groups the participants knew each other well. The artificial constraints of the subject matter notwithstanding, using PDGs as the basis for data generation facilitated the creation of a safe space where my participants' practices with yellow fats could be revealed, questioned, and troubled. ${ }^{2}$ As each participant revealed their yellow fat histories, other group members would comment, ask questions, challenge or support the validity of their narrative. Discussion flowed easily, if in a somewhat scattershot manner, as the participants agreed and disagreed, were confident and selfdeprecating, contradicted themselves, changed their minds, talked across each other, riffed off each other, mocked each other, voiced frustration at the limitations of their own knowledges and information available to them, and expressed surprise at how much they had to say about yellow fats. Yet throughout these discussions, yellow fats were the node through which multiple bodies and relationships were juxtaposed. In this way the conversations shifted from descriptions of shopping, cooking, and eating practices to an exploration of the beliefs, values, and knowledges that were entangled with those practices.

In my analysis, I explore distaste as a means by which my participants negotiate encounters with yellow fats amidst multiple competing knowledges, and show that attending to distaste creates a hesitation through which relations between self and other can be “unpacked." I draw on Probyn's (2000) and Ahmed's (2013) work on disgust as a pushing away of the unwelcome other, and Hayes-Conroy and Hayes-Conroy's (2008) theorization of visceral politics to further explore the entanglement of distasteful "gut feelings" with knowledges, norms, and identity. The information generated from this approach not only pertains to the practices of my participants, but also considers the complex ways in which their routines and regimes with the stuff of fat are negotiated, articulated, and performed. I argue that thinking with distaste extends discussions of the visceral to theorize better the complex interactions between material encounters, sense of self, and styles of valuing the stuff of fats.

\section{Chewing the Fat}

It is perhaps not surprising that within the discussions, taste quickly emerged as an important way in which my participants knew the stuff of fat. Butter was typically described as flavorful. Ruth, for example, had been brought up eating margarine, and recalled first eating butter while on holiday in France "and going bloody hell this is delicious!" When she is talking about her knowledges of butter, Ruth is animated and joyful. She gesticulates, her eyes light up, and "mmm" noises are made. The experience of eating margarine was, however, described by my participants in less lively, less enthusiastic terms. Anna's description of margarine as "quite bland . . . just there to moisturize the bread or something" is a concise reflection of its initial representation within the PDG discussions. At the outset of their conversations, my participants, including the habitual margarine eaters, described the flavor role played by margarine as at best accentuating the palatability of other, more interesting foodstuffs rather than being a remarkable flavor in and of itself. Yet when the conversations moved from discussing generic margarine to specific products, some of these were pronounced as being incredibly flavorful.

Olive-based margarines, in particular, were singled out by my participants because of their distinctive flavor. Claire described the flavor as a bonus, one of the factors shaping her choice of spread. It emerged, however, that the olive flavor was not attractive to Claire primarily because she liked the flavor in or of itself. Claire explained that

I am probably sold on the fact it says olive to be honest . . . If it said sunflower oil, sunflower margarine and it was bright yellow, I'd probably go yuck, but because it's like, it says olive, and you open it and it's, er, lighter, it's not a bright yellow, it's kind of mid-, so yeah.

Although Claire did not particularly like the flavor of olivebased margarine, the presence of the flavor confirmed to her the actuality of olives within the product. The tastefulness of the spread was encountered by her as entwined with her knowledges and beliefs about the healthful activities of olives. She went on to explain that if she was eating a fat in order to enjoy the flavor of that fat on "say a crumpet or a slice of toast," then she would use butter. A gap emerged between Claire's explanations of her visceral liking of the flavor of a product and the experience of the tastefulness of that same product.

Milly, however, felt olive-based margarines to be strongly flavored, but not of olives. This gap between the flavor expected 
and the flavor experienced, revealed something distasteful to Milly about the processes of production. She explained:

the more things are processed, the less close things are to their original form. It's just at some point it must sort of stop really being food, I mean we can eat it, we can eat it and we will feel sated, but... There was a lot in the media back in the 1980s and 1990s about kind of you know the Mediterranean diet and how health ... People lived longer and stuff and that was part of the whole thing that you were being sold that if you introduced elements of this Mediterranean diet. When actually possibly what the Mediterranean diet contained was an awful lot less processed food full stop; you know rather than kind of the idea of having olive margarine, you'd have olives, you'd have olive oil. Rather than eating a processed thing, you'd have things closer to their original form.

Milly experienced distaste in the disjuncture between textual messages about olive-based margarines and the visceral experience of eating them. This distaste was not a product of her knowledges about the ingredients of margarine-Milly knew that margarine contained oils, and she was comfortable with this as she used the same oils in their liquid form. Distaste for Milly was knotted with her beliefs about the "stickiness" (Ahmed 2013) of food processing practices. Milly felt that production processes folded with and in the stuff of margarine in ways that nullified any potential healthful activity of the olives themselves.

Claire and Milly's differing interpretations of the flavor of margarine notwithstanding, their embodied encounters with tastefulness revealed them to be conceptualizing eating as something other than a passive transference of energy from eaten to eater. Eating yellow fats was felt by both Claire and Milly to be an active entanglement of the eating-self and lively matters of fat. The likely healthy or unhealthy activities of the stuff of fat with and in the body of the eater were believed by them to be made present to the eater through the visceral experience of tastefulness. In this way the experience of tastefulness can be understood as a form of "visceral politics" (cf. Hayes-Conroy and Hayes-Conroy 2008) within which matters of fat are differentiated, valued, and enacted.

Ruth, too, trusted her embodied encounters with the stuff of fat to inform her eating practices. She explained that encounters with yellow fats were a visceral prompt to their likely tastefulness. Ruth described the experience of eating margarine as "horrible," "synthetic, really fake." Yet Ruth did not experience distaste because margarine had made her sick, nor because of a primary reaction to the flavors, texture, smell, or appearance of margarine. Indeed she explained that "as a child, we just never had butter, so I never really, just, we had Flora, and I was fine with that." In the intervening years something had shifted in Ruth's experience of her embodied encounters with the stuff of margarine.
In the visceral realm knowledge is embodied and bodies are minded; "representations join and become part of old memories, new intensities, triggers, aches, tempers, commotions, tranquilities" (Hayes-Conroy and Hayes-Conroy 2008: 467). As outlined above, the first time Ruth tasted butter she found it to be delicious; however, her awakening to the tastefulness of butter was not simply a product of flavor. Ruth went on to explain that butter felt to her "like proper food, absolutely lovely. Nourishment!" “Unpacking” Ruth's distasteful encounters with margarine reveals that she felt that the experience of "nourishment" had roused her visceral self to the distasteful "unnatural" otherness of the flavors, smells, and textures of margarine. Ruth encounters the tastefulness of fats with and in her identity and culture, and in combination with her health and other knowledges. The tastefulness of butter shifted the balance of these knowledges. In this way Ruth learned to perceive the production processes of margarine almost as a contagious miasma that fold into, and sully, both margarine and margarine eaters (cf. Ahmed 2013).

Like Ruth, Martin wanted to trust his embodied experience as to what tastes "good" to eat, and he enthusiastically described the visceral "goodness" of butter, pork scratchings, and of bread dipped in hot beef dripping. Yet Martin did not have complete faith in these visceral knowledges. Martin habitually ate margarine, even though he considered it to be functional rather than tasty, explaining that he "went in to buying" margarines because he felt that he was "supposed to be thinking that they're quite healthy." However, he expressed some uncertainty as to how he had come to know this, or even what the stuff of margarine is. Martin explained that he had not "really thought about it, but if you had asked me, I would have thought of margarine as a factory-produced product with various chemicals thrown in, and no doubt heated to very high temperatures, and you know."

Martin had learned that margarine had been designed to do good for, with, and in his body, and he explained that in most circumstances it was an acceptable butter substitute as "it does the job well enough." Yet he went on to describe how he always serves butter, rather than margarine, when feeding guests. Martin judged the functionality of margarine to be doing good for his health, while he deemed the visceral joy of encounters with butter as good for his social relations. Martin understood health and social framings of yellow fats to be incompatible, his yellow fat choices to be slippery depending on which framing is prioritized within the encounter. Thinking with taste facilitates an "unpacking" of the ways in which Martin makes and assesses his yellow fat choices, and shows that he experiences taste in ways that are material and cultural as well as visceral. 
Despite her insistence, Ruth's visceral knowing of the stuff of fat is also not sufficient to explain fully her yellow fat practices. In her narrative Ruth described eating "value butter":

We had an experiment, me and the kids, because I mean things aren't quite so tight now, touch wood, and I hope they'll stay that way, but they were really tight last year and whenever, erm, I sort of thought I'm going to try some of the value products and just see if they're good. Value butter ... passed the taste test, absolutely lovely, literally would not be able to tell the difference ... Butter and salt, nothing else. It's just a pack of butter. And I did say if it's not good we won't stick with it, because we've got to enjoy our food that's really important [and] it was a lot cheaper, so I just went for that.

However, she went on to explain, "I'm not buying value butter now . . . I don't like the value packaging. There is a stigma about it, isn't there . . it's that cultural thing, it's like there's a stigma about those value products." Ruth's belief that the experience of nourishment reveals the stuff of fat as acting with and in her body in ways that are healthful, created space in which the liveliness of the stuff of fat became known to her. However, in her assessment of how value butter can be stigmatizing, Ruth illuminated how such liveliness can, in part, be captured within other knowledge frameworks and sold to consumers as discrete packages subject to "lifestyle choice." She did not just buy any brand of butter, no matter that it tastes "exactly the same." Ruth's experience of the tastefulness of butter was entangled with her material knowledges, her cultural positionality, and her regimes of value (cf. Hayes-Conroy and Hayes-Conroy 2008: 467).

My participants' experience of distastefulness, then, was not merely the product of an encounter with the flavor or texture of the fatty other. The observations of Martin and Ruth suggest that they tasted not only the stuff of margarine, but also other matters, relationships, practices, and discourses that were entangled with it, and stuck to its constituent parts (cf. Abbots and Lavis 2013; Ahmed 2013). When these different ways of knowing were in conflict, compelling them to juggle priorities, Martin and Ruth experienced distaste. By the same token, Jane reported experiencing the visceral pleasure of "good taste" when her different ways of knowing were in alignment. Jane vividly described wanting to trust her embodied experiences of the tasteful nourishment within butter and reported feeling "vindicated" when she read about study findings that suggested that saturated fats may not be implicated in raised cholesterol levels; "I just thought SO I was right all along, you know, I guess that's what lots o fus did . . . it's a taste thing."

All of my participants expressed a desire to make "good" fat choices; however, one participant, Andy, was particularly distinctive in this regard. Andy said that he was deeply concerned about the social and environmental implications of the relationships and connectivities entwined with the stuff of food. He described himself as a careful eater who, despite his low income, habitually buys from "ethical" local businesses, often going without if something is not in stock, out of season, or outside of his price bracket. Andy is also vegan, choosing not to eat butter for sustainability and animal welfare reasons. Unlike Ruth, Andy articulated his knowledges about the bodies and relationships entangled with the stuff of fat as more important to the "goodness" of his eating practices than his visceral experience. Yet for Andy the visceral experience of distastefulness was part of margarine's attraction. He explained that "when we'd be totally cacking ${ }^{3}$ out, we'd go and get a white baguette and then it would just be loads of marg ${ }^{4}$ and some other nasty stuff . . . proper cacky like."

In recalling "cacking out," as when Ruth was describing eating butter, Andy's body language was animated and joyous. Loveliness was not, however, the kind of word he used to describe his experience of eating margarine. Andy described margarine as an overly processed food "substitute." Yet his attempts to juggle multiple regimes of value ensnared with and in his yellow fat choices left him relaying back and forth between the differing distastes of self-denial and culpability. Andy's joyous "naughty" distaste in the self-indulgent rebellion of "cacking out" can be understood as a momentary break from the habitual effort he puts into enacting care for others with and through his mundane eating practices. Sometimes the affectual joy of visceral "wrongness" was a more immediate priority for his self-care than long-term health or ethical concerns.

The touch of fat against lips and mouth constitutes only a small part of webs of relationships between lively bodies entangled with and in the stuff of food (Bennett 2010). From the human labor of animal and plant husbandry, to the multiple life forms that must make space for agriculture, eating cannot happen in isolation (Davis 2003). Elspeth Probyn (2000: 133) suggests that in the experience of distaste "things, categories, people are just too close for comfort." Yet although my participants did describe the embodied experience of eating as a form of knowing that made lively others knotted within the stuff of fats present in their consciousness, the pull of the medicinal felt by Martin and the rebellion described by Andy suggest that sometimes there is a comfort to be found in such closeness.

Distastefulness, then, is not simply a fearful "not-in-mybody" (DuPuis 2000) response to the proximal stranger. My participants experienced a fatty encounter as distasteful when the ways in which the stuff of fat is known and framed revealed disjunctures in the storying of self. As Deleuze (1988: 21) reminds us, "the object that does not agree with me jeopardizes my cohesion, and tends to divide me into subsets, which, in the 

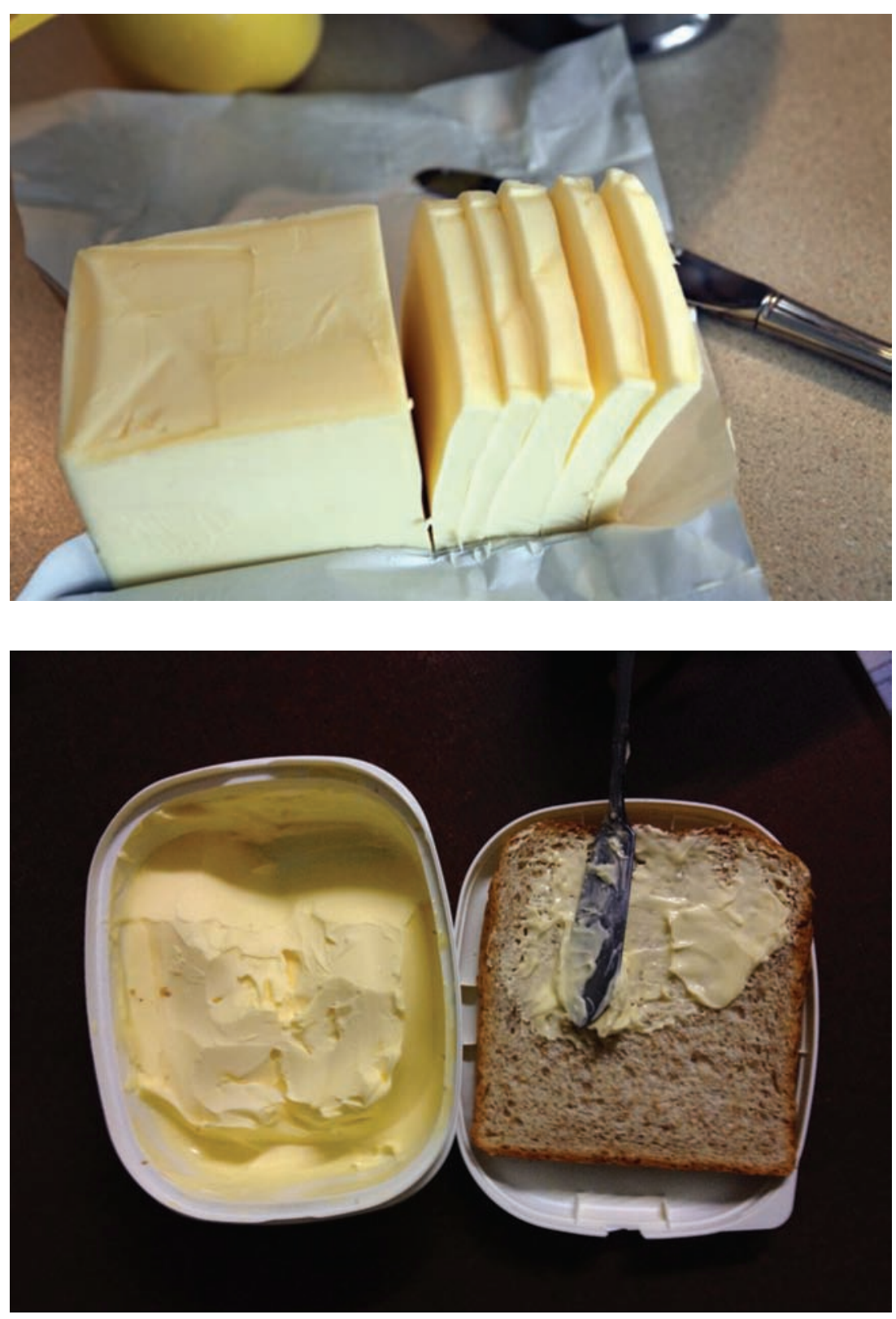

FIGURE 1A (BUTTER) AND IB (MARGARINE): For my research participants, the distastefulness of a yellow fat does not rest in any straightforward way on a visceral disliking of the flavor of that same product.

"HUNK O BUTTER" BY THEPINKPEPPERCORN (WWW.FLICKR.COM/PHOTOS/GAL_THEPINKPEPPERCORN/3516377616/) IS LICENSED UNDER CC BY 2.0; "MARGARINE SPREAD ON BREAD" BY JIMMY TAN (WWW.FLICKR.COM/PHOTOS/JIMMYTST/12648885413/) IS LICENSED UNDER CC BY 2.0.

extreme case, enter into relations that are incompatible with my constitutive relation." Distasteful encounters were an embodied consequence of my participants' attempts to maintain selfcohesion when different regimes of value were in tension.

In this way distasteful encounters momentarily "unpack" normative knowledges, practices, and systemic structures entangled with and in mundane eating practices, making their complex interactions more open to investigation.

\section{Concluding Reflections: "Unpacking” Distasteful Encounters}

I stated at the beginning of this article that food "enters into what we become" (Bennett 2007: 133) and have looked to demonstrate that caring for self through attentiveness to the embodied experiences of eating yellow fats was articulated by my participants as a responsibility they took seriously. It is 
perhaps not surprising that taste emerged as a key mechanism through which my participants came to know the stuff of fat. What is significant, however, is that their perceptions of the distastefulness of a fat did not rest in any straightforward way on their visceral disliking of the flavor of that same product.

Thinking with distaste reveals that my participants' encounters with the stuff of fats cannot be contained to meetings between the stuff of fat and lips, mouth, or guts. My participants did not ingest a fat in any straightforward accordance with their understanding of its flavor or nutritive properties. The stuff of fat was experienced as folded with multiple human and nonhuman others, and they expressed concern about the kinds of bodies and relationships with which they were to become viscerally entangled (cf. Ahmed 2013; Probyn 2000). Yet any practice of relation is also an exclusion of other bodies, communities, and styles of valuing. Distasteful encounters are a tool through which those "that which we have already designated as the beyond" can be made present (Ahmed 2000: 3). The experience of distastefulness is, however, not simply an embodied rejection of perceived topologies of proximity. For my participants, distaste, although shaped by visceral experiences and embodied encounters, was primarily a product of notions of the self being out of accord with the ways in which a fat stuff is framed. The distasteful encounters described by my participants reveal as much about their constructions of self as they do about the object of their distaste.

When attention is paid to the complex and subtle ways in which eaters make and understand their food decisions, "taste" loses its privileged status. In distasteful encounters "material relations and immaterial forces all intersect with individuals' sensory grasp of the world, complicating one's visceral experience" (Hayes-Conroy and Hayes-Conroy 2008: 465). In this article I have demonstrated that thinking with distaste cultivates a hesitation in what "is," and creates space in which tensions and translations between the framings of bodies and relationships entangled with the stuff of fat can be "unpacked" and investigated. However fleetingly, attending to feelings of distaste is a tool through which the enactment of othernesses in "the interactions between different realities" (Law 2004: 122) can be explored. As such, thinking with distaste is an experiment in intensities that can make present not only the ways in which the stuff of fat is encountered by an eater, but also how it was known and valued. In this way thinking with distaste is a tool through which discussions of the visceral can be extended to better theorize the complex interactions between material encounters, sense of self, and styles of valuing the stuff of fats.

\section{Acknowledgments}

This paper is a modified, and hopefully improved, version of a part of my ESRC funded PhD thesis. Many thanks to Steve Hinchliffe and Ian Cook for supporting me through the research, and Louise MacAllister for encouraging me to explore distaste. I am particularly grateful to Emma-Jayne Abbots for seeing potential in the first iteration of this paper, and for her invaluable patience and advice in helping me through the process of turning those initial thoughts into this article.

NOTES

1. For a product to be labeled as margarine in the UK it must have "a fat content of not less than 80\%" (FSA 2010). In this article, however, I have used the word to include "spreadable fats" as is common in colloquial British English.

2. I was introduced to the rest of the group as a trusted friend of the host. Pseudonyms are used throughout.

3. "Cacking out" is a phrase in colloquial UK English which means to "pig out," to binge joyfully on foods with little or no nutritional value. 4. Common abbreviation of margarine.

\section{REFERENCES}

Abbots, Emma-Jayne, and Anna Lavis. 2013. "Contours of Eating: Mapping the Terrain of Body/Food Encounters." In Why We Eat, How We Eat: Contemporary Encounters between Foods and Bodies, ed. Emma-Jayne Abbots and Anna Lavis, 1-12. Farnham: Ashgate.

Ahmed, Sara. 2000. Strange Encounters: Embodied Others in PostColoniality. Abingdon: Routledge.

- 2013. The Cultural Politics of Emotion, Abingdon: Routledge. Bennett, Jane. 2007. "Edible Matter." New Left Review 45: 133-45. . 2010. Vibrant Matter: A Political Ecology of Things. Durham, NC: Duke University Press.

Braidotti, Rosi. 2013. Metamorphoses: Towards a Materialist Theory of Becoming. London: Wiley.

Davis, Steven L. 2003. “The Least Harm Principle May Require that Humans Consume a Diet Containing Large Herbivores, Not a Vegan Diet." Journal of Agricultural and Environmental Ethics 16: 387-94.

Deleuze, Gilles. 1988. Spinoza: Practical Philosophy. Translated by Robert Hurley. San Francisco: City Light.

DuPuis, E. Melanie. 2000. "Not in My Body: BGH and the Rise of Organic Milk." Agriculture and Human Values 17: 285-95.

FSA (Food Standards Agency). 2010. "Guidance on Legislation for Spreadable Fats and Other Yellow Fat Spreads." www.food.gov. uk/sites/default/files/multimedia/pdfs/yellwfatgudanceo610.pdf (accessed 3 March 2015).

Forth, Christopher E. 2014 "Materializing Fat." In Fat Culture and Materiality, ed. Christopher Forth and Alison Leitch, 3-16. London: Bloomsbury.

Hayes-Conroy, Allison, and Jessica Hayes-Conroy. 2008. "Taking Back Taste: Feminism, Food and Visceral Politics." Gender, Place and Culture 12(5): 461-73.

Law, John. 2004. After Method: Mess in Social Science Research. Abingdon: Routledge.

Lunt, Peter, and Sonia Livingstone. 1996. "Rethinking the Focus Group in Media and Communications Research." Journal of Communication 46: 79-98.

O'Reilly, Karen. 2005. Ethnographic Methods. Abingdon: Routledge.

Probyn, Elspeth. 2000. Carnal Appetites: Food, Sex, Identities. New York: Routledge. 